\title{
Editorial
}

\section{The brand as entertainment}

My favourite business read of the moment is Tom Peters 'Liberation Management'. ${ }^{1}$ This editorial column has mentioned Mr Peters before, so I hardly need to explain why. Suffice to say 'Liberation Management' is a business thriller.

The underlying thesis for the book is a relatively straightforward and familiar one: global competition means the whole world is after your slice of the cake; ever more sophisticated and demanding consumers have ever-shifting, ever more customised needs; the growth of information technology increases business ability to answer those needs quickly and efficiently. In summary, modern businesses need to be fast, smart, and flexible to survive. Peter's expression for this is that all business is now fashion business.

'This book is animated by a single word fashion ... the idea of fashion unnerves traditional managers. It demands liberation, everyone exhibiting flair and "bravura", pursuing breath-taking failure as assiduously as success. We're all in Milan's "haute couture" business.'

This quote is in the introduction to 'Liberation Management'. In the next 768 pages, Peters explores this idea of 'business going fashion'. He celebrates the need for 'necessary disorganisation', the need to embrace and maximise risk, not simply manage and minimise it, the need always to question conventions, the need for leaders who anticipate rather than react, the need for passion and joy in business, the need for 'SOBs' to drive a vision forward.

He still promotes the need for businesses to get closer to customers (as he always has done). Indeed, he pushes for business to go further and create 'market symbiosis' and to dismantle the walls between 'them' (purchasers) and 'us' (owners). But he also promotes the need for business to go beyond the consumer for inspiration.

'... get on with all that "close to the customer stuff". Get on with it, yes ... and no. Because there's a sense in which, now, I would counsel not listening to customers at times, and therein lies the real revolution.'

'... we must engage far more intimately with customers (and large numbers of temporary "network" partners) .... But to stand out from the crowd also calls for communing with your own muse and that of quirky partners from around the globe to create startling products and services which respond to needs customers hadn't dreamed they had (and which are completely impermeable to even the cleverest market research).'

'Liberation Management' is a joyful, exuberant book. It celebrates business as one of the great creative exercises of the human mind. It therefore raises high the intuitive, the risky, the dynamic and the entrepreneurial in business management.

But this is an editorial, not a book review. So what can the book teach us as managers of brands?

Directly it tells us very little. In the whole book there are roughly two to three pages on brands and managing brand equity per se (although there are other sections on marketing and on product development) and 
much of this small section is actually based on quotes from other consultants.

'... Stan Davies claims "product" value is best measured by the Intangible/Tangible ratio, adding that the faster you increase your products/IT ratios relative to competitors, the more sustainable your overall competitive position.'

Maybe this lack of comment is comment enough. Obviously, Tom Peters does not come across as many specific brand managers as he does general business managers.

We will, therefore, have to try and work out for ourselves what we think Peters' ideas mean when it comes to managing brands.

On one level, brand managers might recoil at the idea of brands learning from fashion. The fashion industry has not done that great a job at building brands. The constant need to change, to go with the times, to sell this season's collection and adapt to this season's look has often meant that fashion brands often have no long-term values above and beyond whether that season's product is good or bad. The exceptions, such as Levi's or the luxury fashion houses, have actually borrowed lessons from the more 'old-fashioned' concepts of brand management - a clear view of what they stand for, a distinct personality, a valuable set of 'intangibles' nurtured and developed with care over time.

However, having said that, it might be naive of us not to try to stop and think what we can learn. There can be no argument with Peters that Western consumers are becoming ever more sophisticated in their view of brands and what they demand of them. We have seen a first stage move from brands as simple satisfiers of basic functional needs (quality, consistency, superlative performance, etc) into an era where most brands are now also about satisfying consumers emotional and psychological needs (be a good mother/stand out from the crowd/confirm my belief in myself as a connoisseur etc). We might describe this change broadly as being one from unique selling propositions (USPs) to emotional selling propositions (ESPs).

The question Peters prompts is - are we now moving into an era where brand managers have not only to satisfy the consumer's functional and the emotional needs, but also their enjoyment of constant stimulation? Maybe Peters is pointing us towards an era of 'brands as entertainment' or 'emotional and stimulating selling propositions' (ESSPs)? Perhaps we need to recognise that with brands, as with married couples, there is a need not only to build a strong bond of trust, and a powerful sense of emotional kinship, but also to keep the relationship going and keep it fresh. Most divorces occur, after all, because one or other party is simply bored.

If this concept of 'brand as entertainer' is true, then we can learn from fashion and its ability to constantly re-engage the customer, just as much as fashion can learn from us.

Those are the implications of Peters' book for brands. What, if this concept is true, would it imply for us as brand managers?

It might suggest we have to bring new skills to bear on top of our old ones. The new brand manager will constantly be looking for new stimulus (even if guided by a clear and old theme) for the consumer. $\mathrm{He}$ or she will be trying to think of new ways of doing or saying things and will be looking for surprising routes to the consumer, either in the so-called 'new media' or by using old media in a new, unconventional way. This manager will be constantly looking at new ways of leveraging the brand equity, (without diluting it), and new ways of delighting the consumer beyond the basic product.

To do this will take one clear underlying set of skills involving creativity and imagination. In this, I am in total agreement, I think, with Tom Peters in his call for business man- 
agers who are anarchic, unconventional, and 'liberated' in their thinking. In these days of increasing competition leading to increasing parity, this will be our new competitive advantage.

These are my interpretations of what Tom Peters would say to brand managers. I would love to hear Tom Peters talk about brand management himself. But, in his absence, I thought it might be fun to finish this Editorial by writing up a Peters style 'manifesto' or 'to do' list for brand managers based on the general principles of 'Liberation Management'.

\section{A MANIFESTO FOR BRAND MANAGERS (À LA TOM PETERS)}

(1) Brand managers will lead their business in rediscovering the importance and value of humanity, passion and joy.

(2) We will be the creative thinkers in our organisation and create a reputation as the most anti-establishment, anti-bureaucratic, but most exciting, imaginative and productive 'department' in the business.

(3) We will be the 'ideas factory' for how to move the business on as quickly as our organisation, our suppliers and our consumers can cope. We will therefore always try and understand what will satisfy our customers now and in the future.

(4) We will achieve this through a clear and deep understanding of our brand's values both functional and emotional, but we will also always strive to gain fresh insight into those values, and find new ways of communicating them.

(5) To do this we will commission the most stimulating and inspiring research we can to encourage research partners to deliver. We will also create the most interesting and eclectic network of commentators on our business and our brand in the world in order to always ensure fresh, new views on what the future might hold in terms of changing competition and consumer needs.

(6) We will also never be tied by 'research'. We will always commune with our own 'muse' and use our own instincts and trust them, and those of people around us.

(7) We will have fun. We will have boundless energy and enthusiasm.

(8) We will ensure that we pass on that sense of enjoyment and energy to the brands in our care, in order to ensure they are always 'entertaining', ie constantly re-engaging our customers. Our brands will be many splendoured things but never, never boring!

How's that for a manifesto then? Would you like to work in that department? I think I would, although I would also want to check out that the boss had a sense of irony and humour.

We might never, of course, get the chance to join such a marvellous adventure, but we can within this club of a journal, try and ensure we create an environment that is similar. What do you think? Oh, and if Tom Peters is reading this, I genuinely loved the book and I would love the next one to be about brands and brand management.

\section{Nick Kendall Editorial Board}

\section{Reference}

(1) Peters, T. (1992) 'Liberation Management', Macmillan Publishers Ltd, London. 